\title{
LIFE CYCLE ASSESSMENT OF SEWAGE SLUDGE PYROLYSIS: ENVIRONMENTAL IMPACTS OF BIOCHAR AS CARBON SEQUESTRATOR AND NUTRIENT RECYCLER
}

\author{
Fabian Gievers ${ }^{1,2, *}$, Achim Loewen ${ }^{1}$ and Michael Nelles ${ }^{2,3}$ \\ ${ }^{1}$ Faculty of Resource Management, HAWK-University of Applied Sciences and Arts, Rudolf-Diesel-Straße 12, 37075 Göttingen, Germany \\ ${ }^{2}$ Chair of Waste and Resource Management, University of Rostock, Justus-v.-Liebig-Weg 6, 18059 Rostock, Germany \\ ${ }^{3}$ Deutsches Biomasseforschungszentrum gGmbH (DBFZ), The German Centre for Biomass Research, Torgauer Str. 116, 04347 Leipzig, \\ Germany
}

Article Info:

Received:

13 December 2020

Revised:

26 May 2021

Accepted:

14 June 2021

Available online:

11 September 2021

Keywords:

LIfe cycle assessment

Pyrolysis

Sewage sludge

Biochar

Nutrient recovery

Carbon sequestration

\begin{abstract}
The pyrolysis of sewage sludge is an alternative method to recycle the contained nutrients, such as phosphorus, by material use of the resulting biochar. However, the ecological effects of pyrolysis are not easy to evaluate. Therefore, a life cycle assessment (LCA) was carried out to determine the environmental impact of sewage sludge pyrolysis and to compare it with the common method of sewage sludge incineration. In order to identify the most sustainable applications of the resulting biochar, four different scenarios were analyzed. The modeled life cycles include dewatering, drying and pyrolysis of digested sewage sludge and utilization paths of the by-products as well as various applications of the produced biochar and associated transports. The life cycle impact assessment was carried out using the ReCiPe midpoint method. The best scenario in terms of global warming potential (GWP) was the use of biochar in horticulture with net emissions of $2 \mathrm{~g} \mathrm{CO}_{2}$ eq. $/ \mathrm{kg}$ sewage sludge. This scenario of biochar utilization can achieve savings of $78 \%$ of $\mathrm{CO}_{2}$ eq. emissions compared to the benchmark process of sewage sludge mono-incineration. In addition, no ecological hotspots in critical categories such as eutrophication or ecotoxicity were identified for the material use of biochar compared to the benchmark. Pyrolysis of digested sewage sludge with appropriate biochar utilization can therefore be an environmentally friendly option for both sequestering carbon and closing the nutrient cycle.
\end{abstract}

\section{INTRODUCTION}

Pressure on limited natural nutrient resources, such as phosphorus $(P)$, is increasing due to the growing world population and the resulting growing demand for fertilizers to ensure a sufficient food supply. Raw phosphates, which serve as the basis for the production of mineral fertilizers, come from mineral resources extracted mainly in Morocco and China (Cordell \& White, 2011; Schoumans et al., 2015). Another source of $\mathrm{P}$ is municipal wastewater, which could theoretically replace up to $50 \%$ of the mineral $P$ fertilizer applied annually in European agriculture (Egle et al., 2016). Therefore, a long-term strategy is needed to provide natural nutrients and enable waste-based nutrient recycling, especially for potentially critical raw materials like P. This paradigm shift from wastewater treatment as disposal to resource recovery requires new research approaches and treatment technologies and must be guided by the application of green engineering principles to ensure economic, social and environmental sustainability (Peccia \& Westerhoff, 2015). In recent years, most European legislation has agreed on the use of the nutrient and energy value of sewage sludge, but due to transition periods and the conflict between economic challenges and environmental safety, the implementation of new technologies will take decades (Christodoulou \& Stamatelatou, 2016). Therefore, very little $\mathrm{P}$ is currently recovered, as the economics of recovery from waste streams are unfavorable compared to $P$ extracted from mining. The economics could change in the near future as depletion of reserves leads to higher extraction costs and the peak of phosphorus mining could occur by 2030 (Elser \& Bennett, 2011). The total value of $P$ recycling should therefore be considered, including social and environmental aspects (Mayer et al., 2016). The data and the framework for modeling the environmental impact of these elusive aspects of recycling management can be provided by LCA (Haupt \& Hellweg, 2019). 
Existing sewage sludge treatments such as co-combustion in the cement industry or in lignite-fired power plants reduce the $\mathrm{P}$ concentration in the ash and thus make $\mathrm{P}$ extraction more difficult and expensive. An ideal technology should offer maximum $P$ recovery rates, good fertilization properties of the product, removal and destruction of potentially hazardous substances and low environmental and economic risks (Egle et al., 2016; Leinweber et al., 2018). Therefore, the pyrolysis of sewage sludge is a promising approach to implement a circular economy for nutrients and to eliminate pathogens and other organic pollutants (Bridle \& Pritchard, 2004; Frišták et al., 2018; Glaser \& Lehr, 2019; Méndez et al., 2013; Paz-Ferreiro et al., 2018) and carbon sequestration to fight the climate crisis (Alhashimi \& Aktas, 2017; Ennis et al., 2012). Furthermore, pyrolysis fixes and immobilizes the heavy metals in the biochar matrix so that the risk of leaching is minimized compared to the direct agricultural application of the sludge (Agrafioti et al., 2013). In the past, several life cycle assessment (LCA) studies of fast pyrolysis, slow pyrolysis and intermediate pyrolysis of sewage sludge have been carried out to evaluate the sustainability of thermochemical conversion treatments of sewage sludge (Cao \& Pawłowski, 2013; Li \& Feng, 2018; Marazza et al., 2019; Salman et al., 2019; Samolada \& Zabaniotou, 2014; Teoh \& Li, 2020).

In this study, a LCA of the pyrolysis of digested sewage sludge with a special focus on different, biochar applications was carried out and the results were compared with the usual process chain of sewage sludge mono-incineration with subsequent ash landfilling excluding P-recovery. Besides an energetic and environmental evaluation of pyrolysis as a treatment process for sewage sludge, one goal was to determine the best utilization of sewage sludge bi- ochar. Secondary aspects of this study focus on nutrient recycling ability, especially for $P$ (Frišták et al., 2018), and the carbon sequestration potential of the biochar produced (Schmidt et al., 2018).

\section{METHODS}

\subsection{Energy and material flows}

In order to calculate all material and energy flows for the treatment process itself and the subsequent biochar application, a model for the process chains has been generated in the LCA software $\mathrm{GaBi}$ ts. It was assumed that the substrate originates from the anaerobic digestion of sewage sludge in an existing wastewater treatment plant (WWTP) with total solids (TS) content of $5 \%$ (volatile solids (VS): $48 \%$ ). In the model the main parameters of the dewatering, the subsequent drying and the pyrolysis process were set to the following values (Table 1).

\subsubsection{Material flows}

Since all sewage sludge can contain heavy metals and potentially toxic inorganic and organic components, an untreated return of the sludge to the environment is no longer recommended. While organic compounds react during the pyrolysis process, heavy metals cannot be destroyed and accumulate in the biochar. The concentrations of heavy metals must be carefully monitored due to their potential toxic risk (Bauer et al., 2020; van Wesenbeeck et al., 2014), although they may be immobilized by the pyrolysis process (Agrafioti et al., 2013). The milder thermal reaction conditions during pyrolysis can destroy harmful organic substances while maintaining the bio-availability of nutrients such as nitrogen $(\mathrm{N})$, potassium $(\mathrm{K})$ and $\mathrm{P}$, in contrast to the high temperatures during mono-incineration (Glaser \&

TABLE 1: Parameters of digested sewage sludge pyrolysis in the LCA model.

\begin{tabular}{|c|c|c|c|c|}
\hline Process Step & Unit & Value & Range & Reference \\
\hline \multicolumn{5}{|l|}{ Dewatering of the sludge } \\
\hline Input: digested sewage sludge & {$[\mathrm{kg}]$} & 1 & - & Functional unit \\
\hline Input: total solids & {$[\%]$} & 5 & - & ecoinvent database \\
\hline Flocculant & [g] & 0,55 & $0,4-0,7$ & (Denkert et al., 2013) \\
\hline Electricity & {$[\mathrm{kJ}]$} & 7,2 & $6,1-8,4$ & (Denkert et al., 2013) \\
\hline Output: total solids & {$[\%]$} & 25 & $22-30$ & (Denkert et al., 2013) \\
\hline \multicolumn{5}{|l|}{ Drying of the dewatered sludge } \\
\hline Electricity & {$[\mathrm{kJ}]$} & 36 & $32-38$ & Calculated $^{\mathrm{a}}$ \\
\hline Thermal energy & {$[\mathrm{kJ}]$} & 612 & $590-650$ & Calculated \\
\hline Output: total solids & {$[\%]$} & 80 & $78-89$ & Calculated \\
\hline \multicolumn{5}{|l|}{ Pyrolysis } \\
\hline Thermal energy & {$[\mathrm{kJ}]$} & 79 & $50-112$ & Calculated ${ }^{\mathrm{b}}$ \\
\hline Electricity & {$[\mathrm{kJ}]$} & 21 & $15-36$ & Calculated ${ }^{\mathrm{b}}$ \\
\hline Pyrolysis temperature & {$\left[{ }^{\circ} \mathrm{C}\right]$} & 550 & $450-700$ & Estimated $^{\mathrm{b}}$ \\
\hline Residence time & [h] & 1 & $0,3-3$ & Estimated ${ }^{\mathrm{b}}$ \\
\hline Output: biochar & [g] & 23 & $21-30$ & (Tomasi Morgano et al., 2018) \\
\hline Output: gas and liquid & [g] & 30 & $23-32$ & (Tomasi Morgano et al., 2018) \\
\hline
\end{tabular}

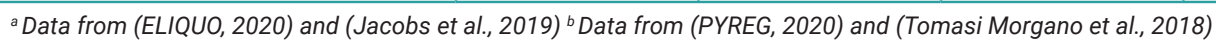


Lehr, 2019; Paneque et al., 2019). To determine the best utilization of biochar, flows and accumulation of heavy metals, organic pollutants and valuable nutrients were modeled using the LCA software. It was assumed that the liquid phase and the gas produced as byproducts in pyrolysis processes will be incinerated on site to generate thermal energy for sludge drying and heating up the pyrolysis process. The press water from the dewatering of digested sewage sludge containing organic substances and nutrients is treated in the on-site WWTP, balanced according to their loads.

\subsubsection{Energy flows}

The energetic modeling of the pyrolysis process was carried out using literature and industrial data. Values for other energy flows, e.g. the electricity required for the dewatering process, were also taken from literature. The emissions of the aggregated background processes originate from the databases of $\mathrm{GaBi}$ and ecoinvent and the data for the benchmark process of sewage sludge mono-incineration were taken from the ecoinvent process, which was adapted to the geographical framework conditions.

\subsection{Life Cycle Assessment}

The LCA was carried out according to the requirements of the ISO 14040 and 14044 standards (Deutsches Institut für Normung, 2009).

\subsubsection{Functional Unit}

In order to compare the pyrolysis of sewage sludge with the given process of mono-incineration and possible other thermochemical treatment methods such as hydrothermal carbonization (Gievers et al., 2019), the functional unit (FU) was defined as "Treatment of $1 \mathrm{~kg}$ of sewage sludge after anaerobic digestion with a total solids content of $5 \% "$.

\subsubsection{System Boundary}

Because mono-incineration currently is mostly recommended as a treatment method for sewage sludge, this technology was used as a benchmark process with which pyrolysis was compared. The system boundary of the modeled system includes the dewatering, drying and pyrolysis of sewage sludge, possible transportation and storage, power and heat generation and four different biochar applications. The energy for the pyrolysis was provided as electricity and thermal energy for the operation of the plant. In this study, the energy content of the pyrolysis gas and the pyrolysis liquid phase was too low to cover the demand for both sludge drying and pyrolysis, so additional energy from the combustion of biogas from sewage sludge digestion was used to provide the required process heat. This was particularly necessary for the start-up phase of the pyrolysis and the upstream drying process. For the utilization of the biochar the avoided burden approach was chosen to take into account the emissions of the processes replaced by the pyrolysis process chains. The use of biochar as a fuel replacing lignite or as a fertilizer replacing NPK fertilizers and peat was compared with the incineration and application of the fossil-based products. For a cascade use of biochar in the biogas process and in agriculture, the saving of maize silage due to the higher biogas yield with biochar was considered. The substitution of lignite was balanced by the energy content of biochar for co-incineration in lignite power plants using existing incineration capacities. The credits for peat in horticulture were calculated by weight, as well as the credits for the fertilizing properties of biochar, adjusted with equivalence factors. For the avoided NPK fertilization, the nutrient content of the biochar was counterbalanced. A total of four different utilization paths (S1-S4) were analyzed and compared with the benchmark process in terms of emissions (Figure 1).

\subsubsection{Modeling Framework}

As pyrolysis is not yet a market-penetrating technology for sewage sludge treatment, it is unlikely that the production and use of biochar as fuel or material will lead to structural changes in the fuel and fertilizer markets in the near future. Therefore, the current study is considered a microlevel decision support (type A) situation according to the ILCD guidelines where an attributional approach was applied in the assessment with generic data from the LCA databases of $\mathrm{GaBi}$ and ecoinvent for the background system. The foreground system includes the process-based model of dewatering, drying, pyrolysis and biochar utiliza-

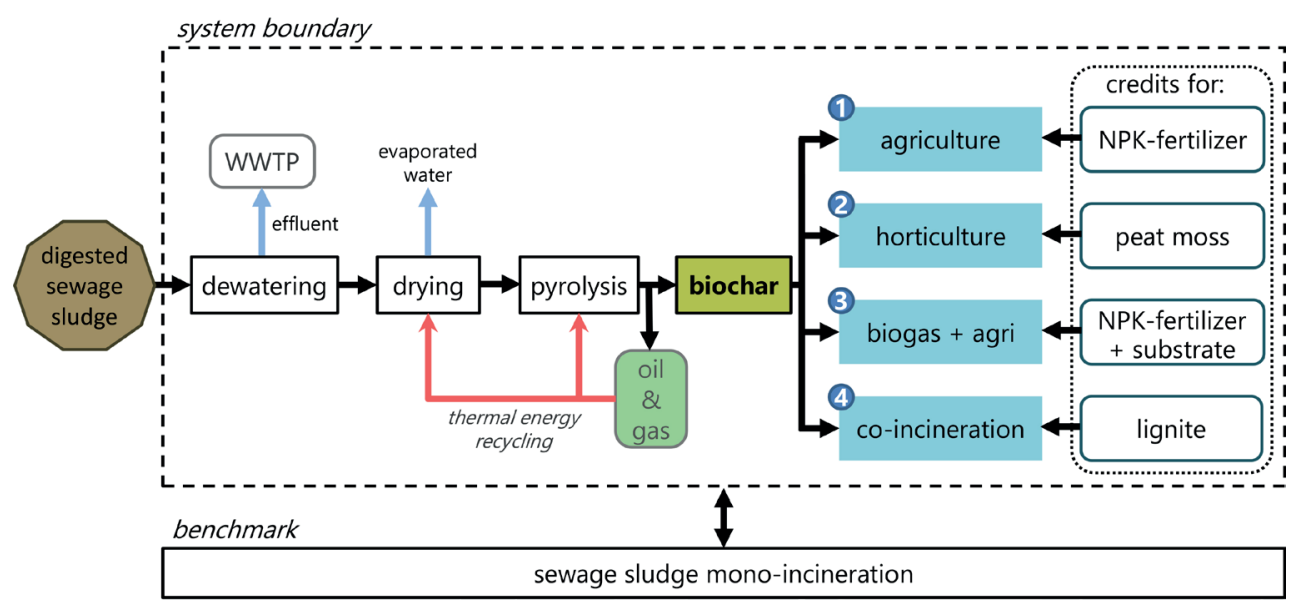

FIGURE 1: System boundary of the investigated sewage sludge to biochar process chains. 
tion. Credits were accounted for cases of aggregated processes with substitution of commodities. The geographical framework of the LCA was the EU.

\subsubsection{LCA-software and Life Cycle Inventory ( $\mathrm{LCl})$ data}

The processes were modeled with the LCA software $\mathrm{GaBi}$ ts (Version 10, sphera solutions $\mathrm{GmbH}$, Leinfelden-Echterdingen, Germany). Life cycle inventory (LCI) datasets provided by $\mathrm{GaBi}$ and ecoinvent (v3.6) (Wernet et al., 2016) were used as data background. Some data concerning the dewatering, drying, pyrolysis and some auxiliary flows were either estimated, calculated or taken from the literature (see Table 1). The biochar characteristics for the LCl were adopted using the values of Table 2. Additional information on $\mathrm{LCl}$ data can be found in the supplementary material.

\subsubsection{Life Cycle Impact Assessment (LCIA)}

Life Cycle Impact Assessment (LCIA) was performed using the ReCiPe 2016 midpoint methodology, as implemented in GaBi ts. In this paper the focus is on GWP measured in $\mathrm{kg} \mathrm{CO}_{2}$ eq. (incl. biogenic carbon) with a Hierarchist $(\mathrm{H})$ perspective, which is based on the most common policy principles and uses a medium time frame of 100 years $(\mathrm{Hu}-$ ijbregts et al., 2017). In order to obtain a complete picture of the environmental impacts of sewage sludge pyrolysis, further LCIA categories were evaluated according to the
ReCiPe method: Stratospheric Ozone Depletion, Ionizing radiation, Fine Particulate Matter Formation, Freshwater Eutrophication, Freshwater Ecotoxicity, Marine Eutrophication, Marine Ecotoxicity, Terrestrial Acidification, Terrestrial Ecotoxicity, Fossil depletion and Human toxicity (cancer and non-cancer).

\subsubsection{Assumptions and limitations}

Due to the lack of data from users of sewage sludgebased biochar in an industrial scale, the material flows including transport routes, the weighting and use of modifications from generic data were determined on the basis of reasonable assumptions, data from pilot plants and literature. In addition, the geographical scope only includes energy mix data from the European Union and only four scenarios were modeled for the use of biochar and one scenario for the benchmark process of mono-incineration and ash landfilling without $P$ recycling. The system boundary is limited to the treatment process after the anaerobic digestion and includes the construction and decommissioning of the pyrolysis plant, the actual pyrolysis process with the incineration of the gas and liquid phase and subsequent heat recovery for sludge drying and linked additional energy supply. Sludge generation processes in WWTP and subsequent sludge digestion were not in the scope of the study. The storage and transport of biochar by truck in the four different scenarios as well as the handling and credits

TABLE 2: Biochar characteristics.

\begin{tabular}{|c|c|c|c|}
\hline Biochar Characteristics & Unit & Value & Source \\
\hline C content & {$\left[\mathrm{kg} \mathrm{kg}^{-1}\right]$} & 0,134 & (Breulmann et al., 2017; Paneque et al., 2017) \\
\hline $\mathrm{C}_{\text {labile }}$ content & {$[\%]$} & 2 & (Breulmann et al., 2017) \\
\hline bulk density & {$\left[\mathrm{Mg} \mathrm{m}^{-3}\right]$} & 0,2 & (Breulmann et al., 2017) \\
\hline calorific value & {$\left[\mathrm{MJ} \mathrm{kg}^{-1}\right]$} & 8,6 & (Tomasi Morgano et al., 2018) \\
\hline P content & {$\left[\mathrm{kg} \mathrm{kg}^{-1}\right]$} & 0,061 & (Breulmann et al., 2017) \\
\hline K content & {$\left[\mathrm{kg} \mathrm{kg}^{-1}\right]$} & 0,012 & (Breulmann et al., 2017) \\
\hline $\mathrm{N}$ content & {$\left[\mathrm{kg} \mathrm{kg}^{-1}\right]$} & 0,009 & (Breulmann et al., 2017; Paneque et al., 2017) \\
\hline Biochar application rate & {$\left[\mathrm{Mg} \mathrm{ha}^{-1}\right]$} & 20 & estimated \\
\hline As content & {$\left[\mathrm{mg} \mathrm{kg}^{-1}\right]$} & 14 & (Song et al., 2014) \\
\hline As leaching concentration & {$\left[\mathrm{mg} \mathrm{kg}^{-1}\right]$} & 3,2 & (Song et al., 2014) \\
\hline Zn content & {$\left[\mathrm{mg} \mathrm{kg}^{-1}\right]$} & 1784 & (Song et al., 2014) \\
\hline Zn leaching concentration & {$\left[\mathrm{mg} \mathrm{kg}^{-1}\right]$} & 6,4 & (Song et al., 2014) \\
\hline $\mathrm{Pb}$ content & {$\left[\mathrm{mg} \mathrm{kg}^{-1}\right]$} & 95,7 & (Song et al., 2014) \\
\hline $\mathrm{Pb}$ leaching concentration & {$\left[\mathrm{mg} \mathrm{kg}^{-1}\right]$} & 1,8 & (Song et al., 2014) \\
\hline Ni content & {$\left[\mathrm{mg} \mathrm{kg}^{-1}\right]$} & 61,5 & (Song et al., 2014) \\
\hline Ni leaching concentration & {$\left[\mathrm{mg} \mathrm{kg}^{-1}\right]$} & 0,3 & (Song et al., 2014) \\
\hline Cd content & {$\left[\mathrm{mg} \mathrm{kg}^{-1}\right]$} & 3,3 & (Song et al., 2014) \\
\hline Cd leaching concentration & {$\left[\mathrm{mg} \mathrm{kg}^{-1}\right]$} & 0,07 & (Song et al., 2014) \\
\hline Cr content & {$\left[\mathrm{mg} \mathrm{kg}^{-1}\right]$} & 58 & (Song et al., 2014) \\
\hline Cr leaching concentration & {$\left[\mathrm{mg} \mathrm{kg}^{-1}\right]$} & 0,2 & (Song et al., 2014) \\
\hline Cu content & {$\left[\mathrm{mg} \mathrm{kg}^{-1}\right]$} & 329 & (Song et al., 2014) \\
\hline Cu leaching concentration & [mg kg-1] & 0,7 & (Song et al., 2014) \\
\hline $\mathrm{PAH}$ (sum) & {$\left[\mu \mathrm{gg}^{-1}\right]$} & 665 & (Zielińska et al., 2016) \\
\hline
\end{tabular}


are included in the system. Where the handling of biochar was not the only activity associated with a process, e.g. the manufacturing of a tractor for use on a farm, the corresponding flows were either allocated (e.g tractor) or neglected (e.g. potential adjustments to the biogas infrastructure). In general, it was estimated that $98 \%$ of the material and $95 \%$ of energy flows were captured in the model. Since sewage sludge is a very inhomogeneous material whose chemical and physical characteristics can vary greatly depending on regional, technical, and seasonal conditions (Twardowska et al., 2004), the most average possible values for the various material and energy flows as well as the biochar and by-products produced were used based on an extensive literature and industrial data research.

Therefore, the uncertainty for that kind of substrate is generally high. Since there is a large variety within the parameters, depending on the technical conditions in the wastewater treatment plant (high substrate diversity), the geographical conditions and the lack of data on the application of sewage sludge biochar on a large scale, the uncertainty is high in comparison to a specific (future) case, where sludge, pyrolysis and biochar parameters are well defined through industrial data and a pyrolysis treatment and a biochar utilization route are established. For the approach in this particular study where the goal was to cover a general European scope and not a specific WWTP and pyrolysis configuration, values out of many studies were conducted to specific aspects of the biochar and technical properties. Thus, the results of the LCA will also be subject to a high degree of uncertainty, which is immanent due to the different conditions and the chosen frame of reference. In addition, many of the generic inventories from the databases are representative of Global or German rather than European conditions, which, in turn decreases the certainty of model outcomes.

\section{RESULTS AND DISCUSSION}

\subsection{Energy and material flows}

The material flows of the entire process chain of treatment of digested sewage sludge and the thermal energy flows of the pyrolysis process with thermal energy recovery were investigated to identify the most important processes and to determine possible options for their optimization. Regarding material flows, the largest mass loss was observed in the thickening process, where about $80 \%$ of the sludge mass can be reduced. In general, only very little of the initial sludge mass is treated by pyrolysis due to the high water content and the necessary pre-treatment for the pyrolysis process, which results in a total solids contents of over $80 \%$ in the dried sludge. About $2,3 \%$ of the input sludge mass ends up in the biochar and $3 \%$ in the oil and gas phase (Figure 2). Therefore a suitable pre-treatment leading to high total and volatile solids loads should be applied (Skinner et al., 2015) to achieve a good energetic performance of the pyrolysis and high biochar yields (Barry et al., 2019; Cao \& Pawłowski, 2012). The treatment of the process water from the thickening process also requires an appropriate process to reduce the chemical oxygen demand (COD) and nitrogen load in the effluent with the aim to improve the environmental performance of the entire process chain (Gourdet et al., 2017). In general, a sludge mass reduction of $97 \%$ can be achieved over the entire process chain, which underlines its application as an efficient treatment process for volume reduction and increasing the transportability of the sewage sludge.

The analysis of the thermal energy flows of the pyrolysis process with energy recycling in the process itself and the upstream drying process shows that $86 \%$ of the thermal energy is used for water evaporation in the drying process (Figure 3 ). Around $52 \%$ of the total thermal energy required can be supplied by the combustion of the pyrolysis oils and gases, while $48 \%$ is supplied externally from biogas generated by the WWTP, which is also reflected in the results of Salman et al. (2019). Drying of the sludge can therefore be supported by the downstream treatment process with additional energy from the upstream digestion process. As the energy recovery potential is strongly influenced by the content of volatile solids in the sludge raw material, it would make sense to use primary and secondary sludge as substrate, but in general the combination of anaerobic

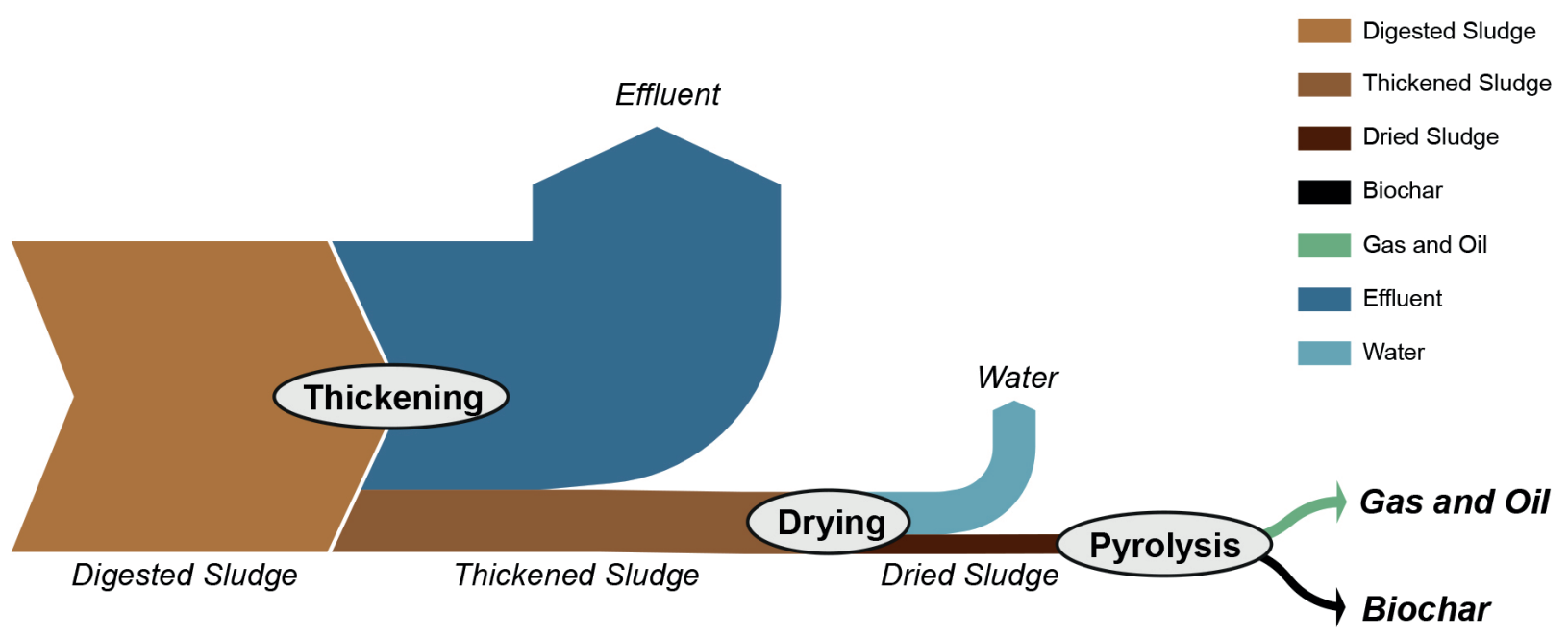

FIGURE 2: Material flows of sewage sludge thickening, drying and pyrolysis. 


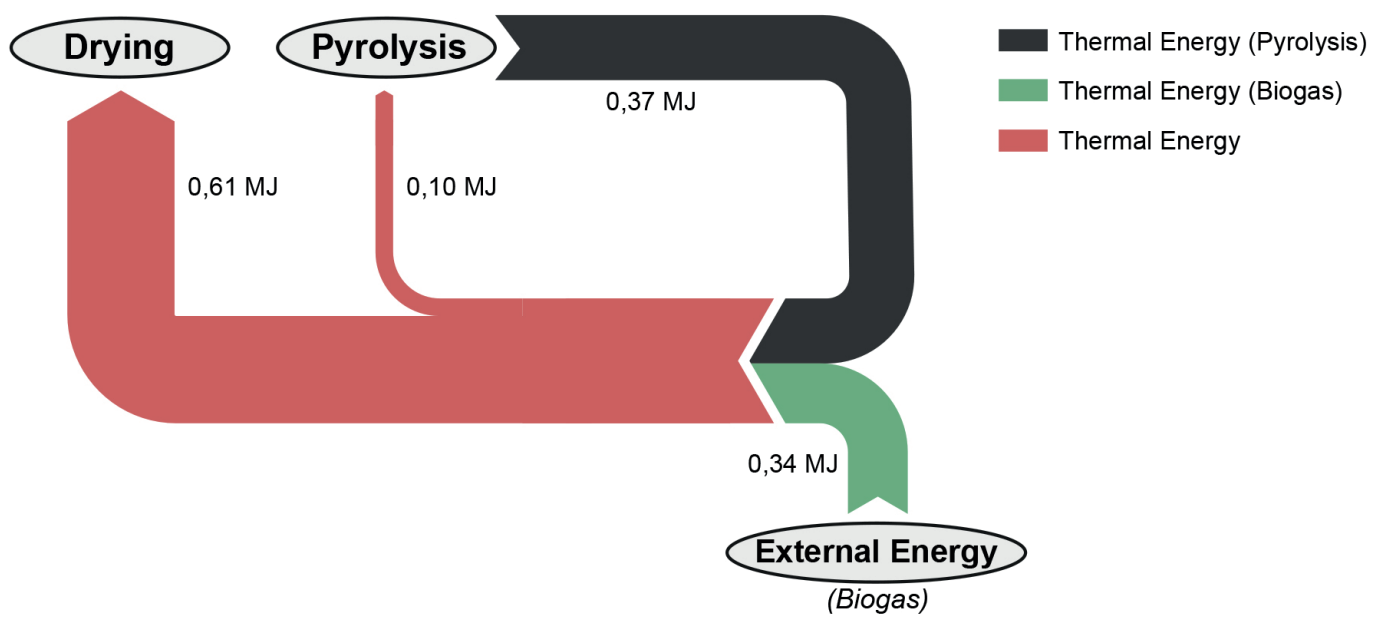

FIGURE 3: Thermal energy flows for the drying and pyrolysis of sewage sludge with an initial total solids content of $5 \%$.

digestion and pyrolysis could achieve a higher energy efficiency compared to pyrolysis of untreated sludge (Cao \& Pawłowski, 2012).

\subsection{Benchmark process of sewage sludge mono-in- cineration}

The benchmark process of sewage sludge digestate mono-incineration was based on a process from the ecoinvent database: [Jungbluth, N., treatment of digester sludge, municipal incineration, future, $\mathrm{CH}$, Substitution, consequential, long-term]. The functional unit of the process refers to the mono-incineration of $1 \mathrm{~kg}$ of wet sludge with $5 \%$ dry solids and is therefore comparable to the results of the pyrolysis model. As commercial pyrolysis of sewage sludge has not yet reached a significant market share, a process adapted by ecoinvent with future emission reductions was chosen as a benchmark process. For the GWP this benchmarking process led to emissions of $7,5 \mathrm{~g} \mathrm{CO}_{2}$ eq. $/ \mathrm{kg} \mathrm{sew}-$ age sludge.

\subsection{Overall GWP of sewage sludge pyrolysis and bi- ochar application}

The distributions of emissions for the sewage sludge treatment process with subsequent utilization scenarios of the biochar were analyzed to identify their environmental impact based on the GWP (Figure 4). Regarding the four biochar scenarios studied, horticultural use of biochar had the lowest net greenhouse gas (GHG) emissions of $1,6 \mathrm{~g} \mathrm{CO}_{2}$ eq./kg sewage sludge. The lignite-fired power plant scenario led to net emissions of $4,2 \mathrm{~g} \mathrm{CO}_{2}$ eq. $/ \mathrm{kg}$ sewage sludge and the scenario with cascade use of biochar resulted in total net emissions of $4,9 \mathrm{~g} \mathrm{CO}_{2}$ eq. $/ \mathrm{kg}$ sewage sludge. All these three scenarios had a lower GWP than the benchmark process of mono-incineration. The scenario of agricultural use of biochar had total emissions of $19,8 \mathrm{~g} \mathrm{CO}_{2}$ eq./kg sewage sludge. Credits for agricultural use of biochar are the lowest of all scenarios due to the relatively low impact of fossil-based fertilizers and the carbon sequestration potential of biochar compared to the substitution of fossil-based materials such as lignite or peat. In contrast to the findings, Mills et al. (2014) calculated a total saving of $30,5 \mathrm{~g} \mathrm{CO}_{2}$ eq./kg sewage sludge with a slightly different system configuration and system boundary, mainly due to electricity generation credits from the pyrolysis process, whereas Li \& Feng (2018) illustrated positive net emissions for a comparable system. Overall, the treatment of digested sewage sludge with dewatering, drying and pyrolysis resulted in emissions of around $25 \mathrm{~g} \mathrm{CO}_{2}$ eq. $/ \mathrm{kg}$ sewage sludge. The contribution of dewatering to the total emissions of the treatment was $29 \%$ and that of drying accounted for $57 \%$. Emissions resulting from the pyrolysis process and the use of the generated liquids and gases for sludge drying contributed $14 \%$ of total treatment emissions. The emissions occurring during drying and dewatering underline the importance of the sludge water content for optimizing the environmental impact of the treatment process. The energy consumption for drying the dewatered sludge generates the greatest contribution to the energy demand of the whole process chain (Table 1) and to the $\mathrm{CO}_{2}$ eq. emissions (Figure 4). As a wide range of energy consumption of dewatering technologies can be observed (Yoshida et al., 2013), an energetic optimisation option of the sludge pyrolysis process chain would be to increase the dry solids and carbon content of the digested sewage sludge with the most energy efficient dewatering technology before the drying process. Another option for further process improvements would be the co-pyrolysis of carbon-rich waste streams such as biowaste. Miller-Robbie et al. (2015) showed that combining agricultural application of sewage sludge with the addition of yard trimmings-biochar could reduce GHG emissions by sequestering carbon in the soil and avoiding fertilizer requirements.

In comparison to the mono-incineration of sewage sludge, the co-incineration of biochar in lignite power plants has a slightly lower emission potential of $4,2 \mathrm{~g} \mathrm{CO}_{2}$ eq. $/ \mathrm{kg}$ sewage sludge. However, due to the imminent phase-out of lignite-based electricity generation in the future and the associated reduction in co-combustion capacities, as well as the high emissions of the burned lignite, it does not make sense to pursue this utilization path further. In addition, the P concentration in the co-incineration ash would be further diluted and $\mathrm{P}$ could not be recycled as with material biochar use. 


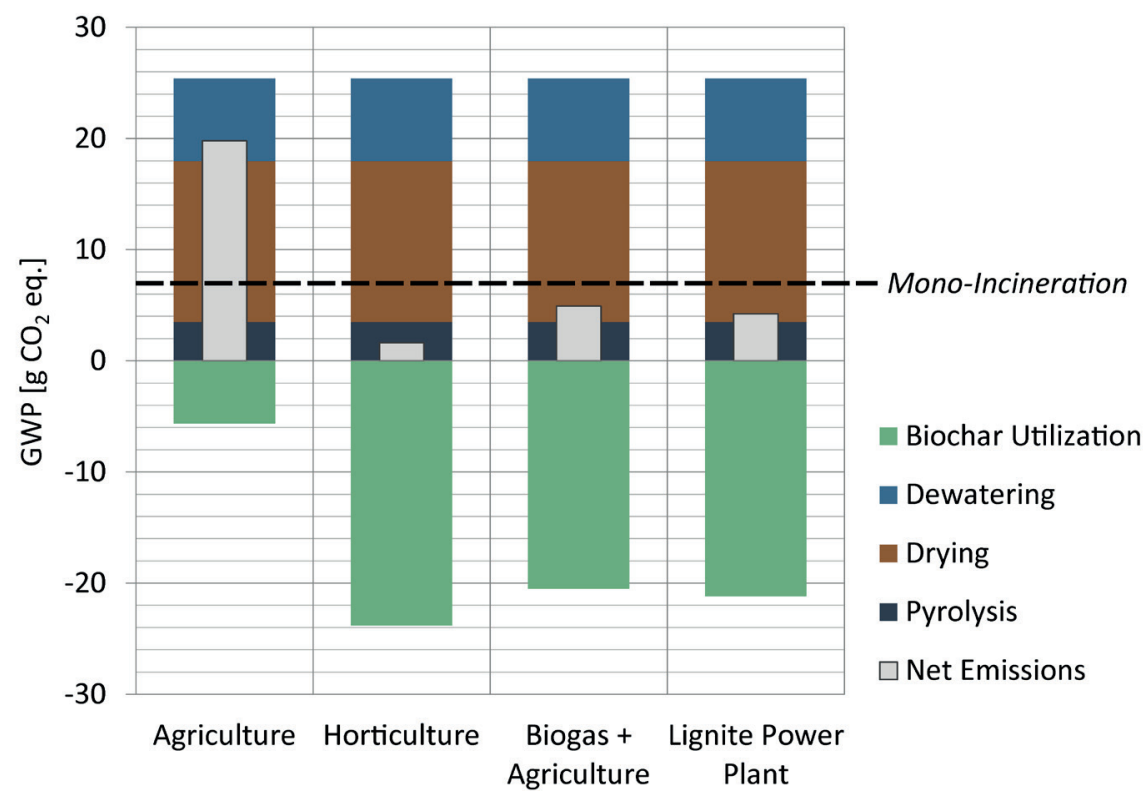

FIGURE 4: Global warming potential (GWP) of the four investigated scenarios of sewage sludge pyrolysis in comparison to the benchmark process.

\subsection{GHG savings through biochar as a carbon se- questrator and nutrient recycler}

Figure 5 shows the GHG emissions of the scenarios resulting from the application of biochar and the generated credits. The greatest amount of GHG reduction (19 $\mathrm{g} \mathrm{CO}_{2}$ eq./kg sewage sludge) was observed for the substitution of peat in horticulture. In the case of cascade use in a biogas plant and in agriculture, the substitution of maize silage due to the higher digestion performance (Yue et al., 2019) of $1 \%$ could achieve a saving of $15 \mathrm{~g} \mathrm{CO}_{2}$ eq./ kg sewage sludge.

The carbon sequestration potential of biochar when used in agriculture or horticulture is relatively low at
$2 \mathrm{~g} \mathrm{CO}_{2}$ eq. $/ \mathrm{kg}$ sewage sludge, as the stable carbon content of biochar from sewage sludge is also very low at around $13 \%$. The carbon sequestration capacity of biochar could be increased by broadening the substrate spectrum, for example by using activated sludge for pyrolysis instead of digested sludge (Cao \& Pawłowski, 2012). With around $4 \mathrm{~g} \mathrm{CO}_{2}$ eq./kg sewage sludge, the substitution of fossil-based NPK fertilizers contributed to the emission savings, mainly due to the $\mathrm{P}$ content of the biochar.

For the scenario of co-incineration of biochar in lignite-fired power plants, savings of $21 \mathrm{~g} \mathrm{CO}_{2}$ eq. $/ \mathrm{kg}$ sewage sludge were observed when energy from fossil lignite was substituted. In general, the contributions to emission re-

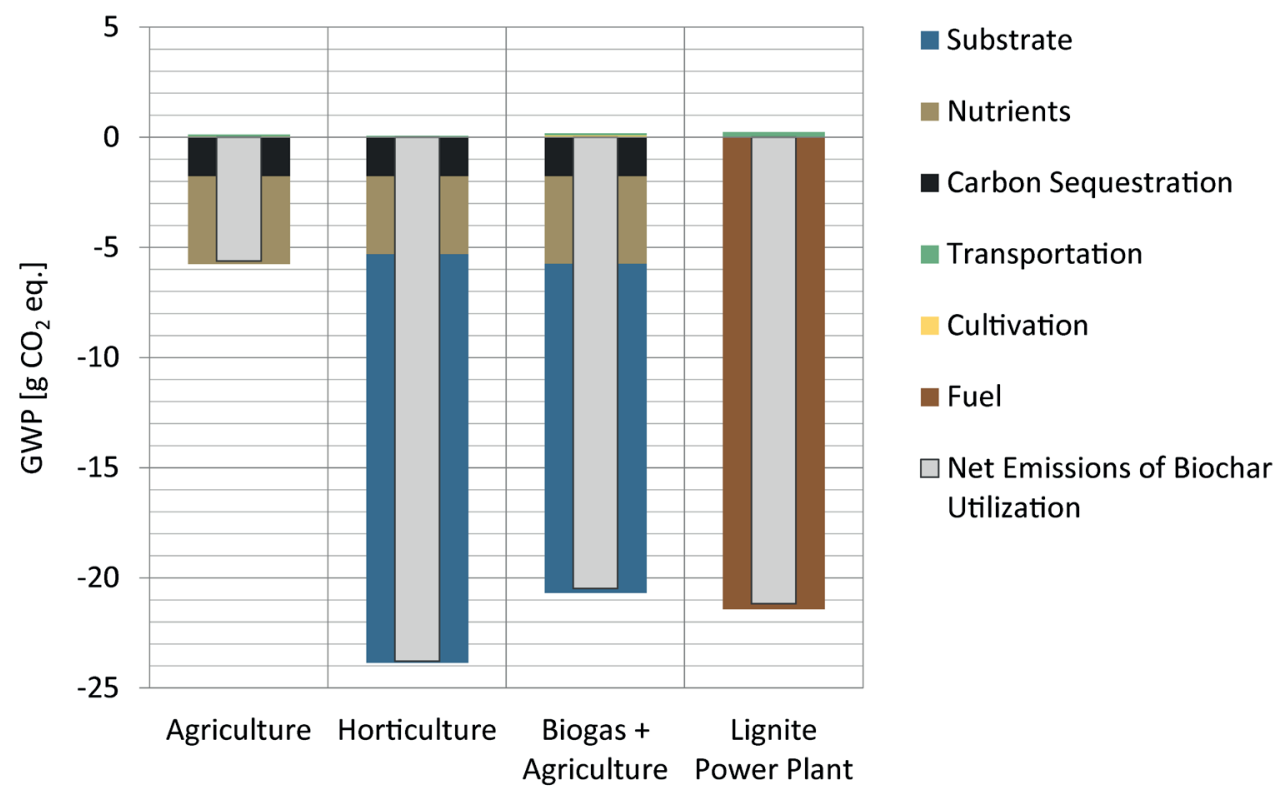

FIGURE 5: GHG emissions of different applications of biochar produced from $1 \mathrm{~kg}$ digested sewage sludge. 
duction through carbon sequestration and $P$ recycling of biochar are below the credits derived from replacing fossil materials such as lignite and peat. In all scenarios, the emissions caused by the transport and handling of biochar were comparably low. Furthermore, the results show that cascade use of biochar could increase the benefits compared to single use.

\subsection{Results of other LCIA categories}

To evaluate the overall environmental performance of the sewage sludge-to-biochar system, several LCIA categories in addition to GWP were evaluated and compared to the benchmark process. The net emissions for each scenario (S1-S4) are shown in Table 3 and the comparison with the benchmark process $(100 \%)$ is illustrated in Figure 6.

Figure 6 shows the percentage of net emissions of the different scenarios compared to the benchmark. For all scenarios (S1-S4), results for impact categories regarding (terrestrial, freshwater and marine) ecotoxicity and (freshwater and marine) eutrophication were all lower than the benchmark impacts $(0,1 \%$ to $40 \%)$, although nutrient flows and potential toxic contaminants like heavy metals and polycyclic aromatic hydrocarbons (PAH) were included in the model. In contrast, impacts on terrestrial acidification, ionizing radiation and stratospheric ozone depletion exceeded benchmark emissions up to $190 \%$. Compared to the benchmark scenario, each scenario resulted in very low human toxicity (cancer), freshwater ecotoxicity and marine ecotoxicity potential, regardless of whether the biochar was used as a material or as an energy source (2-3\%). The emissions contributing to this impact category depend mainly on the heavy metal content of the biochar and its re-solubility into the environment, but also on the relatively high loads of heavy metals (e.g. chromium) of the generic benchmark process in comparison. Non-cancer human toxicity results were also lower than the benchmark emissions in all scenarios. The category with the greatest differences within the scenarios was fossil depletion. For the substitu- tion of lignite overall savings of $-30 \%$ could be accounted while for the agricultural use (S1) and the combined biogas and agricultural use (S3) fossil depletion were higher than the baseline (170\% and $157 \%$ ) which was mainly due to the higher consumption of fossil fuels by agricultural activity (S1 and S3) and the substitution of lignite (S4). For terrestrial acidification, only S3 had lower emissions compared to the benchmark (71\%) which can be explained with the credits from the saved maize cultivation. A similar pattern is also evident for stratospheric ozone depletion, where the biogas and agriculture scenario had a lower impact compared to the benchmark (62\%). Only in this category the horticultural scenario (S2) performed the worst, resulting in the highest emissions of $146 \%$ compared to the benchmark.

In general, the cascade use of biochar in biogas plants and agriculture (S3) resulted in the lowest impact in most categories, with exception of GWP, ionizing radiation and fossil depletion. The horticulture scenario (S2) was the best in terms of GWP impacts and due to peat substitution, the fossil depletion potential was very low. Even the co-incineration scenario in lignite power plants (S4) in some categories can lead to lower impacts compared to the benchmark. This can be explained by the very poor environmental performance of lignite combustion for power generation compared with the European grid mix. However, the material use of biochar showed no environmental hotspot in critical categories for agricultural use such as eutrophication or ecotoxicity compared to the benchmark, although all potentially critical substance flows such as heavy metals and PAH were represented in the model. For example, the innovative use of biochar in a cascade to exploit multiple positive effects can achieve nutrient recycling while keeping the environmental impacts low.

\subsection{Sensitivity analysis}

Sensitivity analyses were conducted for (1) the electricity and thermal energy consumptions of the pyrolysis

TABLE 3: LCIA emissions of the investigated scenarios (S1-S4).

\begin{tabular}{|c|c|c|c|c|c|c|}
\hline \multirow{2}{*}{ LCIA Category (ReCiPe, 2016) } & \multirow{2}{*}{ Unit } & \multicolumn{4}{|c|}{ Scenario } & \multirow{2}{*}{$\begin{array}{c}\text { Benchmark } \\
\text { Mono-Incineration }\end{array}$} \\
\hline & & Agri (S1) & Horti (S2) & Biogas + Agri (S3) & Lignite (S4) & \\
\hline Global Warming Potential & [kg CO${ }_{2}$ eq. $]$ & $1,98 \mathrm{E}-02$ & $1,62 \mathrm{E}-03$ & $4,91 \mathrm{E}-03$ & $4,23 \mathrm{E}-03$ & $7,45 \mathrm{E}-03$ \\
\hline Fine Particulate Matter Formation & {$\left[\mathrm{kg} \mathrm{PM} \mathrm{P}_{2,5}\right.$ eq. $]$} & $2,79 \mathrm{E}-05$ & $2,52 \mathrm{E}-05$ & 1,87E-05 & 2,83E-05 & $2,64 \mathrm{E}-05$ \\
\hline Fossil Depletion & [kg oil eq.] & $4,84 \mathrm{E}-03$ & $6,73 E-05$ & $4,48 \mathrm{E}-03$ & $-8,43 E-04$ & $2,85 \mathrm{E}-03$ \\
\hline Freshwater Ecotoxicity & [kg 1,4 DB eq.] & $8,46 \mathrm{E}-05$ & $6,10 \mathrm{E}-05$ & $3,92 \mathrm{E}-06$ & $8,37 \mathrm{E}-05$ & $2,81 \mathrm{E}-03$ \\
\hline Freshwater Eutrophication & [kg P eq.] & $1,01 \mathrm{E}-05$ & $9,66 \mathrm{E}-06$ & $8,11 \mathrm{E}-06$ & 2,69E-05 & $6,69 \mathrm{E}-05$ \\
\hline Ionizing Radiation & [Bq. Co-60 eq. to air] & $7,45 \mathrm{E}-04$ & $6,60 \mathrm{E}-04$ & $7,14 \mathrm{E}-04$ & 7,47E-04 & $3,94 \mathrm{E}-04$ \\
\hline Marine Ecotoxicity & [kg 1,4 DB eq.] & $1,10 \mathrm{E}-04$ & $7,91 \mathrm{E}-05$ & $1,52 \mathrm{E}-05$ & $1,08 \mathrm{E}-04$ & $3,39 \mathrm{E}-03$ \\
\hline Marine Eutrophication & [kg N eq.] & $5,51 \mathrm{E}-05$ & $5,51 \mathrm{E}-05$ & $4,42 E-05$ & $5,50 \mathrm{E}-05$ & $1,56 \mathrm{E}-04$ \\
\hline Stratospheric Ozone Depletion & [kg CFC-11 eq.] & $1,10 \mathrm{E}-07$ & $1,15 \mathrm{E}-07$ & $4,86 \mathrm{E}-08$ & $1,05 \mathrm{E}-07$ & $7,86 \mathrm{E}-08$ \\
\hline Terrestrial Acidification & [kg SO${ }_{2}$ eq.] & $1,07 \mathrm{E}-04$ & $1,03 E-04$ & $5,06 \mathrm{E}-05$ & $1,04 \mathrm{E}-04$ & 7,17E-05 \\
\hline Terrestrial Ecotoxicity & [kg 1,4 DB eq.] & $1,18 \mathrm{E}-02$ & $8,15 \mathrm{E}-03$ & $7,58 \mathrm{E}-03$ & $7,19 \mathrm{E}-03$ & $2,53 \mathrm{E}-02$ \\
\hline Human Toxicity, cancer & [kg 1,4 DB eq.] & $1,53 \mathrm{E}-04$ & $1,17 \mathrm{E}-04$ & $1,05 \mathrm{E}-04$ & $1,52 \mathrm{E}-04$ & $5,09 \mathrm{E}-03$ \\
\hline Human Toxicity, non-cancer & [kg 1,4 DB eq.] & $2,16 \mathrm{E}-02$ & $2,06 \mathrm{E}-02$ & $9,62 \mathrm{E}-03$ & $1,37 \mathrm{E}-02$ & $2,89 \mathrm{E}-02$ \\
\hline
\end{tabular}




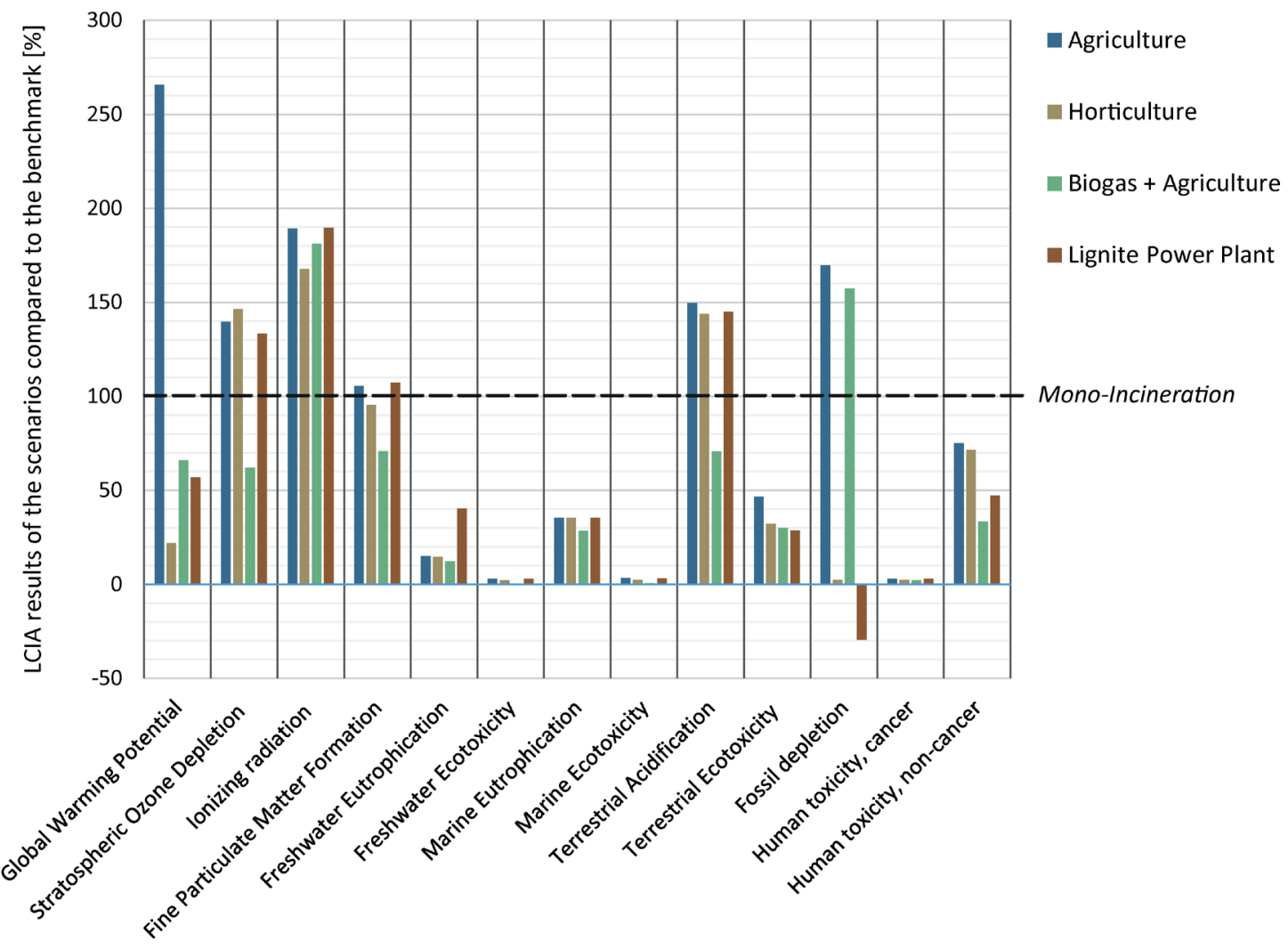

FIGURE 6: LCIA results of different biochar applications compared to the benchmark scenario of mono-incineration.

process, the drying step and the dewatering process, (2) the nutrients $(\mathrm{N}, \mathrm{P}$, and $\mathrm{K})$, Carbon and heavy metals $(\mathrm{Pb}$, $\mathrm{Cd}$ and $\mathrm{Cr}$ ) contents of the biochar for the scenarios with material use of biochar (S1-S3) and (3) the calorific value of the biochar for scenario S4. Within the parameter variation, all other parameter values were the same as in the reference scenario or as in the baseline values in the scenarios S1-S4. Sensitivity of parameters changes $( \pm 10 \%)$ to LCIA results was conducted by comparing LCIA results with and without parameter changes. If the ratios are positive, the environmental impact increases with an increase in the parameter value and vice versa (see Supplementary Material, Table A.3, Table A.4, Table A.5, Table A. 6 and Table A.7). Parameters with an absolute LCIA category change of less than $2,5 \%$ are considered insensitive. For the sake of clarity, only the results for the most sensitive parameters were explained further. Regarding the influence of the increased electricity demand of the pretreatment steps and pyrolysis, a small net emission increase of about $2,5 \%$ in the pyrolysis process and $3,3 \%$ in the drying process could only be found for fossil depletion and ionizing radiation, resulting from the generic electricity mix based on partially nuclear and fossil fuels electricity. The sensitivity of heat demand for the drying process indicates, that a minute variation can have a major effect on the resulting impacts, which was also revealed by Cao \& Pawłowski (2013). For the GWP an increase of $8,4 \%$ and for fossil depletion an increase of $3,9 \%$ were determined for an heat demand increase of $10 \%$. Other categories with a noteable increase were marine ecotoxicity and marine eutrophication (13,8\% and 3,5\%), freshwater eutrophication (3\%), stratospheric ozone depletion (14,3\%), fine particulate matter formation (13,9\%) and terrestrial acidification (13,4\%). In general, higher electricity and thermal energy demands resulted in higher emissions in the respective categories due to the associated emissions within the generic processes. In particular, the model is quite sensitive to the thermal energy input of the drying process. These results are consistent with earlier work from Li \& Feng (2018), which found that the dewatering and drying processes also played a key role in the determination of the assessment results.

Results for the biochar characteristics variation (2) showed that only the $\mathrm{C}$ and $\mathrm{P}$ concentrations affected the categories GWP and fossil depletion in nearly all scenarios. In general, it was found that an increase in nutrient and carbon levels caused a reduction in emissions. This can be explained by the credits from the avoided product systems and the $\mathrm{C}$ sequestration properties of the biochar, although the $C$ sequestration potential is highly variable and depends on the particular soil conditions and biochar substrates (Schmidt et al., 2018) and in some cases an increase in the $\mathrm{C}$ content of the biochar may even result in a lower C sequestration potential (Santín et al., 2017). In addition, Li \& Feng (2018) showed that varying the VS/TS ratio, and thus the carbon content, in the feedstock sludge can lead to very different environmental impact profiles. An increase or decrease in leachable heavy metal contents had no significant effect on any category, also not to the toxicity-relevant. 
The sensitivity regarding the calorific value of the biochar was high for GWP, fossil depletion, terrestrial acidification, terrestrial ecotoxicity and particulate matter formation where a $10 \%$ increase had a decrease in emissions of $-56 \%$ to $56,0 \%,-8 \%$ to $-8,0 \%$ and $-3 \%$ to $-3,0 \%$. The main reason for that was the substitution of fossil-based energy from lignite. Since the modeled emissions from biochar are based on carbon content and not calorific value, there is greater uncertainty in the model regarding the energy use of biochar. For this reason, energy use was evaluated as a possible exception to the material utilization of biochar.

Other important assumptions concern substitution of products and processes, because avoided impacts often had a significant effect. Different choices concerning fertilizing properties or the mix and amount of electricity and thermal energy would have led to different results. In particular, the model is sensitive to the thermal energy input of the drying process and the $\mathrm{C}$ and especially $\mathrm{P}$ content of the biochar.

\section{CONCLUSIONS}

Energy and nutrient recovery from sewage sludge represents an important strategic lever for sustainable management of sewage sludge in an emerging bioeconomy. In this study, a LCA was conducted to determine whether pyrolysis is more sustainable than mono-incineration and whether biochar can be a sustainable form of fertilizer that simultaneously sequesters carbon. The results of the LCA show that substituting fossil based material and fuel (peat and lignite) with biochar has the highest potential to reduce the climate change impact of sewage sludge treatment. In comparison to the benchmark process of mono-incineration, the scenarios of biochar application in horticulture, biochar in cascade use in anaerobic digestion and agriculture and the energetic use in lignite power plant has lower emissions. The analyses of the material flows show that the main flows, which consist mainly of water, are separated before the pyrolysis process. Thus, the pyrolysis process can reduce the original sludge mass by $97 \%$. It was also revealed that the energy flows of the pyrolysis process chain can achieve higher energy efficiency and lower emissions if thermal energy from the pyrolysis process can be recycled and biogas from the upstream anaerobic digestion process can be used in the sludge drying process. For the environmental performance examplified in the GWP, the use of biochar as a material has a similar GHG saving potential than its use in existing fossil fuel based power plants. Especially if the biochar can be used in a cascade (S3), first in anaerobic digestion to improve process parameters and then in agriculture to sequester carbon and close the nutrient cycle, GHG savings can be generated. Remarkably, the use of biochar in agriculture without an additional utilization step (S1) has a lower GHG savings potential than the use in lignite-fired power plants (S4) and in horticulture (S2). The overall environmental impacts determined from the results of the other LCIA categories indicate that no potential hot spots were detected. In particular, for critical categories directly affected by biochar material use, such as ecotoxicity to environmental compartments, human tox- icity or eutrophication, the analysis showed that all biochar use scenarios perform better than the benchmark. However, six categories perform worse than the benchmark for some scenarios: global warming potential, fossil depletion, terrestrial acidification, ionizing radiation, and stratospheric ozone depletion.

In general, improvements in LCIA methodology are needed in order to evaluate future benefits of the sludge treatment process and biochar utilization, such as recycling of nutrients and soil improvement aspects and general improvements like pathogen reduction. For biochar as a carbon sequestrator, a high carbon content in the untreated sludge is needed with suitable process settings of the pyrolysis. Further LCA studies should therefore be carried out with different input sludges and various volatile solids concentrations. With regard to the recyclability of $P$ through the pyrolysis process, it was determined that almost the entire $\mathrm{P}$ content of the sludge is accumulated in the biochar. This could ensure an effective nutrient recycling without any further downstream treatment. Overall, the results show that in some cases, compared to the incineration of sewage sludge, it is possible to reduce GHG emissions while at the same time closing the $\mathrm{P}$ and (partially) the $\mathrm{C}$ cycles and minimizing environmental risks of potentially toxic substances like heavy metals or $\mathrm{PAH}$.

\section{ACKNOWLEDGEMENTS}

This work was funded with federal state resources from the Ministry of Science and Culture of Lower Saxony in the framework of the program "Niedersächsisches Vorab". We would also like to thank Tobias Roether from the "3N Competence Center Lower Saxony Network Renewable Resources and Bioeconomy e.V." for the intensive and inspiring discussions during the development of the LCA model and the reviewers of this paper for their constructive comments, which helped to improve the quality of the paper.

\section{REFERENCES}

Agrafioti, E., Bouras, G., Kalderis, D. \& Diamadopoulos, E. (2013). Biochar production by sewage sludge pyrolysis. Journal of Analytical and Applied Pyrolysis, 101, 72-78. https://doi.org/10.1016/j. jaap.2013.02.010

Alhashimi, H. A. \& Aktas, C. B. (2017). Life cycle environmental and economic performance of biochar compared with activated carbon: A meta-analysis. Resources, Conservation and Recycling, 118, 13-26. https://doi.org/10.1016/j.resconrec.2016.11.016

Bauer, T., Andreas, L., Lagerkvist, A. \& Burgman, L. E. (2020). EFFECTS OF THE DIFFERENT IMPLEMENTATION OF LEGISLATION RELATING TO SEWAGE SLUDGE DISPOSAL IN THE EU. Detritus(10), 9299. https://doi.org/10.31025/2611-4135/2020.13944

Barry, D., Barbiero, C., Briens, C. \& Berruti, F. (2019). Pyrolysis as an economical and ecological treatment option for municipal sewage sludge. Biomass and Bioenergy, 122, 472-480. https://doi. org/10.1016/j.biombioe.2019.01.041

Breulmann, M., van Afferden, M., Müller, R. A., Schulz, E. \& Fühner, C. (2017). Process conditions of pyrolysis and hydrothermal carbonization affect the potential of sewage sludge for soil carbon sequestration and amelioration. Journal of Analytical and Applied Pyrolysis, 124, 256-265. https://doi.org/10.1016/j.jaap.2017.01.026

Bridle, T. R. \& Pritchard, D. (2004). Energy and nutrient recovery from sewage sludge via pyrolysis. Water Science and Technology, 50(9), 169-175. https://doi.org/10.2166/wst.2004.0562 
Cao, Y. \& Pawłowski, A. (2012). Sewage sludge-to-energy approaches based on anaerobic digestion and pyrolysis: Brief overview and energy efficiency assessment. Renewable and Sustainable Energy Reviews, 16(3), 1657-1665. https://doi.org/10.1016/j. rser.2011.12.014

Cao, Y. \& Pawłowski, A. (2013). Life cycle assessment of two emerging sewage sludge-to-energy systems: evaluating energy and greenhouse gas emissions implications. Bioresource Technology, 127 81-91. https://doi.org/10.1016/j.biortech.2012.09.135

Christodoulou, A. \& Stamatelatou, K. (2016). Overview of legislation on sewage sludge management in developed countries worldwide. Water science and technology: a journal of the International Association on Water Pollution Research, 73(3), 453-462. https://doi. org/10.2166/wst.2015.521

Cordell, D. \& White, S. (2011). Peak Phosphorus: Clarifying the Key Issues of a Vigorous Debate about Long-Term Phosphorus Security. Sustainability, 3(12), 2027-2049. https://doi.org/10.3390/ su3102027

Denkert, R., Kopp, J., Meyer, H., Wolf, S., Ewert, W., Lou, U., Melsa, A., Roediger, M. \& Sievers, M. (2013). Merkblatt DWA-M 366: Maschinelle Schlammentwässerung (2013. Aufl.). DWA-Merkblatt: M 366. Deutsche Vereinigung für Wasserwirtschaft Abwasser und Abfall.

Deutsches Institut für Normung. (2009). Umweltmanagement - Ökobilanz - Grundsätze und Rahmenbedingungen: (ISO 14040:2006); deutsche und englische Fassung EN ISO 14040:2009 (Deutsche Norm DIN EN ISO 14040). Berlin

Egle, L., Rechberger, H., Krampe, J. \& Zessner, M. (2016). Phosphorus recovery from municipal wastewater: An integrated comparative technological, environmental and economic assessment of $P$ recovery technologies. The Science of the total environment, 571 , 522-542. https://doi.org/10.1016/j.scitotenv.2016.07.019

ELIQUO. (2020). EloDry® sewage sludge drying technology. Retrieved from https://www.eliquo-we.com/en/elodry.htm

Elser, J. \& Bennett, E. (2011). Phosphorus cycle: A broken biogeochemical cycle. Nature, 478(7367), 29-31. https://doi. org/10.1038/478029a

Ennis, C. J., Evans, A. G., Islam, M., Ralebitso-Senior, T. K. \& Senior, E. (2012). Biochar: Carbon Sequestration, Land Remediation, and Impacts on Soil Microbiology. Critical Reviews in Environmental Science and Technology, 42(22), 2311-2364. https://doi.org/10.1080 110643389.2011 .574115

Frišták, V., Pipíška, M. \& Soja, G. (2018). Pyrolysis treatment of sewage sludge: A promising way to produce phosphorus fertilizer. Journal of Cleaner Production, 172, 1772-1778. https://doi.org/10.1016/j. jclepro.2017.12.015

Gievers, F., Loewen, A. \& Nelles, M. (2019). Hydrothermal Carbonization (HTC) of Sewage Sludge: GHG Emissions of Various Hydrochar Applications. In: L. Schebek, C. Herrmann, F. Cerdas (eds), Sustainable Production, Life Cycle Engineering and Management. Progress in Life Cycle Assessment (Bd. 142, P. 59-68). Springer International Publishing. https://doi.org/10.1007/978-3-319-92237-9_7

Glaser, B. \& Lehr, V.-I. (2019). Biochar effects on phosphorus availability in agricultural soils: A meta-analysis. Scientific reports, 9(1), 9338 https://doi.org/10.1038/s41598-019-45693-z

Gourdet, C., Girault, R., Berthault, S., Richard, M., Tosoni, J. \& Pradel, M. (2017). In quest of environmental hotspots of sewage sludge treatment combining anaerobic digestion and mechanical dewatering: A life cycle assessment approach. Journal of Cleaner Production, 143, 1123-1136. https://doi.org/10.1016/j.jclepro.2016.12.007

Haupt, M. \& Hellweg, S. (2019). Measuring the environmental sustainability of a circular economy. Environmental and Sustainability Indicators, 1-2, 100005. https://doi.org/10.1016/j.indic.2019.100005

Huijbregts, M. A. J., Steinmann, Z. J. N., Elshout, P. M. F., Stam, G., Verones, F., Vieira, M., Zijp, M., Hollander, A. \& van Zelm, R. (2017). ReCiPe2016: A harmonised life cycle impact assessment method at midpoint and endpoint level. The International Journal of Life Cycle Assessment, 22(2), 138-147. https://doi.org/10.1007/ s11367-016-1246-y

Jacobs, U., Fehr, G., Geyer J., Heindl, A., Husmann, M., Kellermann, H.G., Lehrmann, F., Ritterbusch, S., Schönfeld, R., Tomalla, M., Beatt, B., Hanßen, H., Haselwimmer, T., Hochsgürtel, H., Hüppe, P., Jasper, M., Kappa, S., Kristkeitz, R., Ludwig, P., Maurer, M.; Pietsch, B.; Schmittel, P. Six, J.: Stamer, F., Werther, J. (2019). Merkblatt DWA-M 379 Klärschlammtrocknung (Entwurf) (2019. Aufl.). DWA-Regelwerk: Bd. 379. Deutsche Vereinigung für Wasserwirtschaft, Abwasser und Abfall.
Leinweber, P., Bathmann, U., Buczko, U., Douhaire, C., Eichler-Löbermann, B., Frossard, E., Ekardt, F., Jarvie, H., Krämer, I., Kabbe, C., Lennartz, B., Mellander, P.-E., Nausch, G., Ohtake, H. \& Tränckner, J. (2018). Handling the phosphorus paradox in agriculture and natural ecosystems: Scarcity, necessity, and burden of P. Ambio, 47(Suppl 1), 3-19. https://doi.org/10.1007/s13280-017-0968-9

Li, H. \& Feng, K. (2018). Life cycle assessment of the environmental impacts and energy efficiency of an integration of sludge anaerobic digestion and pyrolysis. Journal of Cleaner Production, 195, 476-485. https://doi.org/10.1016/j.jclepro.2018.05.259

Marazza, D., Macrelli, S., D’Angeli, M., Righi, S., Hornung, A. \& Contin, A. (2019). Greenhouse gas savings and energy balance of sewage sludge treated through an enhanced intermediate pyrolysis screw reactor combined with a reforming process. Waste management, 91, 42-53. https://doi.org/10.1016/j.wasman.2019.04.054

Mayer, B. K. Baker, L. A , Boyer, T. H., Drechsel, P, Gifford, M., Hanjra, M. A., Parameswaran, P., Stoltzfus, J., Westerhoff, P. \& Rittmann, B. E. (2016). Total Value of Phosphorus Recovery. Environmental science \& technology, 50(13), 6606-6620. https://doi.org/10.1021/ acs.est.6b01239

Méndez, A., Terradillos, M. \& Gascó, G. (2013). Physicochemical and agronomic properties of biochar from sewage sludge pyrolysed at different temperatures. Journal of Analytical and Applied Pyrolysis, 102, 124-130. https://doi.org/10.1016/j.jaap.2013.03.006

Miller-Robbie, L., Ulrich, B. A., Ramey, D. F., Spencer, K. S., Herzog, S. P., Cath, T. Y., Stokes, J. R. \& Higgins, C. P. (2015). Life cycle energy and greenhouse gas assessment of the co-production of biosolids and biochar for land application. Journal of Cleaner Production, 91, 118-127. https://doi.org/10.1016/j.jclepro.2014.12.050

Mills, N., Pearce, P., Farrow, J., Thorpe, R. B. \& Kirkby, N. F. (2014). Environmental \& economic life cycle assessment of current \& future sewage sludge to energy technologies. Waste management, 34(1), 185-195. https://doi.org/10.1016/j.wasman.2013.08.024

Paneque, M., Knicker, H., Kern, J. \& La Rosa, J. M. de (2019). Hydrothermal Carbonization and Pyrolysis of Sewage Sludge: Effects on Lolium perenne Germination and Growth. Agronomy, 9(7), 363. https://doi.org/10.3390/agronomy9070363

Paneque, M., La Rosa, J. M. de, Kern, J., Reza, M. T. \& Knicker, H. (2017) Hydrothermal carbonization and pyrolysis of sewage sludges: What happen to carbon and nitrogen? Journal of Analytical and Applied Pyrolysis, 128, 314-323. https://doi.org/10.1016/j. jaap.2017.09.019

Paz-Ferreiro, J., Nieto, A., Méndez, A., Askeland, M. P. J. \& Gascó, G. (2018). Biochar from Biosolids Pyrolysis: A Review. International journal of environmental research and public health, 15(5). https:// doi.org/10.3390/ijerph15050956

Peccia, J. \& Westerhoff, P. (2015). We Should Expect More out of Our Sewage Sludge. Environmental science \& technology, 49(14), 8271-8276. https://doi.org/10.1021/acs.est.5b01931

PYREG. (2020). sewage sludge. Retrieved from https://www.pyreg.de/ wp-content/uploads/2020_pyreg_brochure_sludge_EN.pdf

Salman, C. A., Schwede, S., Thorin, E., Li, H. \& Yan, J. (2019). Identification of thermochemical pathways for the energy and nutrient recovery from digested sludge in wastewater treatment plants. Energy Procedia, 158, 1317-1322. https://doi.org/10.1016/j. egypro.2019.01.325

Samolada, M. C. \& Zabaniotou, A. A. (2014). Comparative assessment of municipal sewage sludge incineration, gasification and pyrolysis for a sustainable sludge-to-energy management in Greece. Waste management (New York, N.Y.), 34(2), 411-420. https://doi. org/10.1016/j.wasman.2013.11.003

Santín, C., Doerr, S. H., Merino, A., Bucheli, T. D., Bryant, R., Ascough, P., Gao, X. \& Masiello, C. A. (2017). Carbon sequestration potential and physicochemical properties differ between wildfire charcoals and slow-pyrolysis biochars. Scientific reports, 7(1), 11233. https://doi.org/10.1038/s41598-017-10455-2

Schmidt, H.-P., Anca-Couce, A., Hagemann, N., Werner, C., Gerten, D., Lucht, W. \& Kammann, C. (2018). Pyrogenic carbon capture and storage. GCB Bioenergy, 38(1), 215. https://doi.org/10.1111/ gcbb. 12553

Schoumans, O. F., Bouraoui, F., Kabbe, C., Oenema, O. \& van Dijk, K. C (2015). Phosphorus management in Europe in a changing world Ambio, 44 Suppl 2, 92. https://doi.org/10.1007/s13280-014-0613-9

Skinner, S. J., Studer, L. J., Dixon, D. R., Hillis, P., Rees, C. A., Wall, R. C. Cavalida, R. G., Usher, S. P., Stickland, A. D. \& Scales, P. J. (2015). Quantification of wastewater sludge dewatering. Water research, 82, 2-13. https://doi.org/10.1016/j.watres.2015.04.045 
Song, X. D., Xue, X. Y., Chen, D. Z., He, P. J. \& Dai, X. H. (2014). Application of biochar from sewage sludge to plant cultivation: Influence of pyrolysis temperature and biochar-to-soil ratio on yield and heavy metal accumulation. Chemosphere, 109, 213-220. https:// doi.org/10.1016/j.chemosphere.2014.01.070

Teoh, S. K. \& Li, L. Y. (2020). Feasibility of alternative sewage sludge treatment methods from a lifecycle assessment (LCA) perspective. Journal of Cleaner Production, 247, 119495. https://doi. org/10.1016/j.jclepro.2019.119495

Tomasi Morgano, M., Leibold, H., Richter, F., Stapf, D. \& Seifert, H. (2018). Screw pyrolysis technology for sewage sludge treatment. Waste management (New York, N.Y.), 73, 487-495. https://doi. org/10.1016/j.wasman.2017.05.049

Twardowska, I., Schramm, K.-W. \& Berg, K. (2004). Sewage sludge. In I. Twardowska (Hg.), Waste Management Series. Solid Waste: Assessment, Monitoring and Remediation (Bd. 4, S. 239-295). Elsevier. https://doi.org/10.1016/S0713-2743(04)80013-8

van Wesenbeeck, S., Prins, W., Ronsse, F. \& Antal, M. J. (2014). Sewage Sludge Carbonization for Biochar Applications. Fate of Heavy Metals. Energy \& Fuels, 28(8), 5318-5326. https://doi.org/10.1021/ ef500875c
Wernet, G., Bauer, C., Steubing, B., Reinhard, J., Moreno-Ruiz, E. \& Weidema, B. (2016). The ecoinvent database version 3 (part I): Overview and methodology. The International Journal of Life Cycle Assessment, 21(9), 1218-1230. https://doi.org/10.1007/s11367016-1087-8

Yoshida, H., Christensen, T. H. \& Scheutz, C. (2013). Life cycle assessment of sewage sludge management: a review. Waste management \& research: the journal of the International Solid Wastes and Public Cleansing Association, ISWA, 31(11), 1083-1101. https:// doi.org/10.1177/0734242X13504446

Yue, X., Arena, U., Chen, D., Lei, K. \& Dai, X. (2019). Anaerobic digestion disposal of sewage sludge pyrolysis liquid in cow dung matrix and the enhancing effect of sewage sludge char. Journal of Cleaner Production, 235, 801-811. https://doi.org/10.1016/j.jclepro.2019.07.033

Zielińska, A. \& Oleszczuk, P. (2016). Effect of pyrolysis temperatures on freely dissolved polycyclic aromatic hydrocarbon (PAH) concentrations in sewage sludge-derived biochars. Chemosphere, 153, 68-74. https://doi.org/10.1016/j.chemosphere.2016.02.118 